\title{
HLA-DR antigens in tuberculoid and lepromatous leprosy
}

\author{
THOMAS H REA* \& PAUL I TERASAKI $\dagger$ \\ *Section of Dermatology, Department of Internal Medicine, \\ University of Southern California School of Medicine; Department \\ of Dermatology, University of Southern California-Los Angeles \\ County Medical Center; and † Department of Surgery, University \\ of California School of Medicine, Los Angeles, California
}

\section{Received for publication 19 November 1979}

Summary The frequencies of distribution of six histocompatibility antigens of the HLA-DR locus were determined in 38 Mexican patients with lepromatous leprosy and in 19 Mexican patients with tuberculoid leprosy. These were compared with antigen frequencies of 174 Mexicans who did not have leprosy. No evidence of an association between HLA-DR antigens and leprosy could be found. In tuberculoid subjects HLA-DRW2 was more common than in controls, $32 \%$ and $15 \%$ respectively. Although this difference was not statistically significant, it was in accord with another report of a significant increase in HLA-DRW2 among patients with tuberculoid leprosy. Furthermore, frequencies for $16 \mathrm{HLA}-\mathrm{A}, 23 \mathrm{HLA}-\mathrm{B}$ and five HLA-C antigens did not differ significantly in the two groups of patients as compared with controls.

\section{Introduction}

An association has been sought repeatedly between leprosy and antigens of the HLA-A and HLA-B loci of the major histocompatibility complex (Chan et al., 1979; ${ }^{1}$ Dasgupta et al., 1975; de Vries et al., 1976; ${ }^{3}$ Escobar-Gutierrez et al., $1973 ;{ }^{4}$ Greiner et al., 1978; ${ }^{5}$ Kriesler et al., 1974; $;^{6}$ Massoud et al., 1978; ${ }^{7}$ Rea et al., 1976; Reis et al., 1974; ${ }^{8}$ Smith et al., 1975;10 Takata et al., 1978; ${ }^{11}$ Thorsby et al., 1973;12 and Youngchaiyud et al., 1977 ${ }^{13}$ ). The at least 13 studies reported to date collectively attest to the attractiveness of evidence suggesting that susceptibility to, and mode of expression of, leprosy is under genetic control (Chakravartti and Vogel, 1973; ${ }^{14}$ Newell, 1966; ${ }^{15}$ and Spickett 1962a, ${ }^{16}$

Correspondence to Dr Thomas H. Rea, Department of Dermatology, LAC/USC Medical Center, 2025 Zonal Avenue, Los Angeles, California 90033. 
$\left.1962 b^{17}\right)$. In four of these 13 studies statistically significant associations with an HLA-A (Kriesler et al., 19746) or HLA-B (Chan et al., 1979; ${ }^{1}$ Takata et al., 1978;11 and Thorsby et al., 197312) antigen were found, after correction by multiplying the p-value by the number of specificities tested. Greiner et al. $(1978)^{5}$ reasoned that this multiplying method of correction was not adequate because frequencies of various antigens are not independent; instead, relative risk was calculated as a measure of the significance of an association. However, whatever method was used to establish statistical significance, even among studies reporting significance, there has been no consistent association of a particular HLA-A and HLA-B antigen with any particular type of leprosy or with leprosy in general. Differing pressures for linkage disequilibrium in differing populations was an attractive explanation for the discordant, but yet significant findings (de Vries et al., 1976). ${ }^{3}$

Study of HLA-A and HLA-B haplotype inheritance has provided further evidence that susceptibility to, and type of, leprosy may be influenced by genes within the major histocompatibility complex (de Vries et al., 1976; ${ }^{3}$ Fine et al., $\left.1979^{18}\right)$.

Because the HLA-D and HLA-DR loci are nearer to the hypothetical immune response (Ir) gene than are $\mathrm{HLA}-\mathrm{A},-\mathrm{B}$, or $-\mathrm{C}$ loci, and because antigens of HLA-D or HLA-DR loci may show a closer association to a particular disease than can be detected by typing for HLA-A, $-\mathrm{B}$, or $-\mathrm{C}$ antigens (Rachelefsky et al., 1976;19 and Reinertsen et al., $1978^{20}$ ), it is logical that an association of HLA-D and HLA-DR antigens with leprosy has been sought. Stoner et al. $(1978)^{21}$ tested in vitro lymphoproliferative responses to Mycobacterium leprae in HLA-D identical and non-identical siblings of patients with lepromatous leprosy; finding that the HLA-D identical siblings responded as well as the HLA-D non-identical, they concluded that the $M$. leprae unresponsiveness of lepromatous patients was not the result of an HLA-D or -D-linked gene. In a preliminary report, de Vries et al. (1979) ${ }^{22}$ found no evidence of an association between lepromatous leprosy and HLADR antigens; however, a statistically significant increase in HLA-DRW2 frequency in tuberculoid patients was present. We herein report our study of HAL-DR antigen frequencies in Mexican patients with leprosy.

\section{Patients and methods}

Patients were classified according to the histological and clinical criteria of Ridley and co-workers (Ridley, 1974; Ridley and Jopling, 1962; and Waters, $1969^{25}$ ). Because of the high incidence of erythema nodosum leprosum and Lucio's reaction, a histological distinction between polar and subpolar lepromatous leprosy could not be made (Ridley, 1974; ${ }^{23}$ Ridley and Waters, $1969^{25}$ ). However, by clinical criteria all patients classed as lepromatous 
were polar lepromatous (Ridley and Waters, 1969). ${ }^{25}$ Thus 36 of 38 patients had or had had either erythema nodosum leprosum of Lucio's reaction, but never a reversal reaction. Also no patient had had a well-defined plaque clinically characteristic of subpolar lepromatous leprosy (Ridley and Waters, 1969). ${ }^{25}$ Three of the 38 lepromatous patients showed a slight unilateral contraction of the fourth and fifth fingers but without associated asymmetrical sensory loss or muscle atrophy; other than this there was no suggestion of nerve trunk palsies. Finally, 18 of the 38 lepromatous subjects were known to have had diffuse, non-nodular lepromatous leprosy prior to beginning chemotherapy.

All of the tuberculoid patients were classified as BT (borderline with tuberculoid features). Most were typical of the BT classification. One patient showed some TT (polar tuberculoid) features by histological criteria and others TT by clinical criteria; but none were TT by both clinical and histological criteria.

All patients were Mexican-born or of bilateral Mexican-American ancestry. Controls were Mexican and Mexican-American blood bank and tissue transplant donors.

The microlymphocytotoxic method was employed (Mittal et al., 1968). ${ }^{26}$ B-lymphocytes were separated from T-lymphocytes by adherence to nylon wool. Six HLA-DRW antigens were sought, 1-5 and 7 (HLA-DRW6 was sought but is not reported because it probably does not exist). In addition to HLA-DR, 16 HLA-A, 23 HLA-B and five HLA-C antigens were sought.

Statistical analysis employed the $\psi^{2}$ test with the Yates' correction.

\section{Results}

The results are summarized in Table 1 for HLA-DR and in Table 2 for HLA$\mathrm{A},-\mathrm{B}$ and $-\mathrm{C}$ antigens.

HLA-DRW2 was more common in tuberculoid patients $(32 \%)$ than in controls (15\%), but the difference was not statistically significant even uncorrected, $\psi^{2}=2.33, \mathrm{p}>0.1$. In the 38 lepromatous patients there was not even a suggestion of a genuine difference in antigen frequency distribution as

Table 1. Frequencies (\%) of distributions of HLA-DR antigens in patients and controls

\begin{tabular}{rccc}
\hline Antigen & $\begin{array}{c}\text { Controls } \\
(174)\end{array}$ & $\begin{array}{c}\text { Tuberculoid } \\
\text { Leprosy } \\
(19)\end{array}$ & $\begin{array}{c}\text { Lepromatous } \\
\text { Leprosy } \\
(38)\end{array}$ \\
\hline HLA DRW 1 & 20 & 11 & 21 \\
2 & 15 & 32 & 13 \\
3 & 20 & 26 & 13 \\
4 & 38 & 26 & 42 \\
5 & 15 & 16 & 13 \\
7 & 14 & 16 & 16 \\
\hline
\end{tabular}


Table 2. Frequencies (\%) of distribution of $\mathrm{HLA}-\mathrm{A},-\mathrm{B}$ and $-\mathrm{C}$ antigens in patients and controls

\begin{tabular}{|c|c|c|c|}
\hline Antigen & $\begin{array}{c}\text { Controls } \\
(332)\end{array}$ & $\begin{array}{c}\text { Tuberculoid } \\
\text { Leprosy } \\
\text { (19) }\end{array}$ & $\begin{array}{c}\text { Lepromatous } \\
\text { Leprosy } \\
(44)\end{array}$ \\
\hline $\mathrm{HLA}-\mathrm{A} 1$ & 12 & 11 & 7 \\
\hline $\mathrm{A} 2$ & 50 & 32 & 64 \\
\hline $\mathrm{A} 3$ & 9 & 21 & 14 \\
\hline All & 14 & 16 & 2 \\
\hline A 25 & 2 & 0 & 0 \\
\hline A 26 & 8 & 21 & 7 \\
\hline A 28 & 19 & 26 & 23 \\
\hline A29 & 9 & 0 & 11 \\
\hline AW 23 & 5 & 5 & 2 \\
\hline AW 24 & 28 & 32 & 32 \\
\hline AW 30 & 7 & 5 & 11 \\
\hline AW31 & 10 & 11 & 14 \\
\hline AW32 & 7 & 5 & 2 \\
\hline AW33 & 5 & 5 & 2 \\
\hline AW 34 & 0 & 0 & 0 \\
\hline AW36 & 0 & 0 & 0 \\
\hline HLA-B7 & 8 & 11 & 9 \\
\hline B8 & 6 & 5 & 11 \\
\hline B 13 & 1 & 0 & 5 \\
\hline B 14 & 11 & 16 & 14 \\
\hline B 15 & 9 & 0 & 7 \\
\hline B 17 & 5 & 0 & 5 \\
\hline B 18 & 6 & 16 & 2 \\
\hline HLA-B27 & 6 & 0 & 0 \\
\hline B37 & 2 & 5 & 2 \\
\hline B.40 & 21 & 16 & 18 \\
\hline BW 22 & 0 & 0 & 0 \\
\hline BW35 & 33 & 37 & 36 \\
\hline BW 38 & 11 & 21 & 14 \\
\hline BW39 & 10 & 5 & 2 \\
\hline BW42 & 2 & 11 & 0 \\
\hline BW44 & 16 & 11 & 11 \\
\hline BW 45 & 2 & 0 & 7 \\
\hline BW49 & 4 & 0 & 2 \\
\hline BW 50 & 4 & 0 & 5 \\
\hline BW51 & 12 & 5 & 11 \\
\hline BW52 & 8 & 0 & 2 \\
\hline BW53 & 0 & 0 & 0 \\
\hline BW54 & 1 & 0 & 2 \\
\hline $\mathrm{HLA}-\mathrm{CW} 1$ & 8 & 5 & 0 \\
\hline $\mathrm{CW} 2$ & 8 & 11 & 0 \\
\hline CW 3 & 25 & 26 & 16 \\
\hline CW4 & 31 & 47 & 30 \\
\hline CW 5 & 0 & 0 & 0 \\
\hline
\end{tabular}


compared with controls; the greatest difference was with HLA-DRW3 and had a p-value of greater than 0.3. Likewise, antigen frequencies for the HLA-A,

$-\mathrm{B}$ and $-\mathrm{C}$ loci did not differ significantly in the two groups of patients and in the controls.

\section{Discussion}

No evidence of an association between an HLA-DR antigen and leprosy could be found. However, the finding of a higher incidence of HLA-DRW2 in tuberculoid patients than in controls was in accord with the results of de Vries et al. (1979). ${ }^{22}$ Although not statistically significant with these small numbers, our data is consistent with an association between HLA-DRW2 and tuberculoid leprosy. Furthermore, the similarity of antigen frequencies in the lepromatous patients and in the controls indicates that stratification between the leprosy patients and the rontrols was unlikely. Differences between our findings and those of de Vries et al. (1979) ${ }^{22}$ could be explained by differences in patient classification or pressures for linkage disequilibrium. Also genetic differences might be anticipated, as part of an explanation for the high prevalence rate of tuberculoid leprosy among populations studied by de Vries et al. $\left(1976,{ }^{3} 1979^{22}\right), 10$ per 1000 or more, but the low prevalence rate of tuberculoid leprosy among Mexicans (Villarreal, 1979) ${ }^{27} 0.03$ per 1000 - a difference of over two orders of magnitude.

Two studies of HLA-DR antigen frequencies (de Vries et al., 1979, ${ }^{22}$ and the present study) and the study by Stoner et al. (1978) ${ }^{21}$ have provided no evidence of an association between lepromatous leprosy and antigens of the HLA-DR and HLA-D loci. These negative findings do not undo the evidence that susceptibility to lepromatous leprosy is under genetic control, but suggest that the critical gene(s) will not be found in the major histocompatibility complex. That is to say, the controlling gene(s) for lepromatous leprosy will prove to be neither an HLA antigen nor linked to an HLA antigen. Perhaps leprosy in man may be analogous to Listeria monocytogenes infection in mice (Skamene et al., 1979), ${ }^{28}$ where resistance and susceptibility are under genetic control outside of the H-2 complex, but footpad reactions to L. monocytogenes antigens appear to be linked to the $\mathrm{H}-2$ complex.

\section{Acknowledgements}

This study was supported in part by a research grant from The Victor Heiser Awards for Research in Leprosy. Access to the patients of the US Public Health Service Clinic in San Pedro, California and the San Diego County Public Health Clinic was graciously provided by Dr John Gebhard and Dr Antonio Lopez. 


\section{References}

${ }^{1}$ Chan SH, Oon BB, Kamarudin A, Wee GB. HLA and Leprosy in Chinese. Tissue Antigens, $1979,13,73$.

2 Dasgupta A, Mehra NK, Ghei SK, Vaidya MC. Histocompatibility antigens in leprosy. Tissue Antigens, 1975, 5, 85 .

3 de Vries RRP, Lai A Fat RFM, Nijenhuis LE, van Rood JJ. HLA-linked genetic control of host response to Mycobacterium leprae. Lancet, 1976, 2, 1328.

4 Escobar-Gutierrez A, Gorodezky C, Salazar-Mallen M. Distribution of some of the HLAA system lymphocyte antigens in Mexicans Vox Sang, 1973, 25, 151.

${ }^{5}$ Greiner J, Schleiermacher E, Smith T, Lenhard V, Vogel F. The HLA system and leprosy in Thailand. Hum. Genet, 1978, 42, 201.

${ }^{6}$ Kreisler M, Arnaiz A, Perez B, Cruz EF, Bootello A. HL-A antigens in leprosy. Tissue Antigens, 1974, 4, 197.

7 Massoud A, Nikbin B, Nazari GR, Syadat NA, Ala F. A study of cell-mediated immunity and histocompatibility antigens in leprosy patients in Iran. Int J Lepr, 1978, 46, 149.

8 Rea TH, Levan NE, Terasaki P. Histocompatibility antigen in patients with leprosy. J Infect Dis, 1976, 134, 615.

9 Reis AP, Maia F, Reis VF, Andrade IM, Campos AAS. HL-A antigens in leprosy. Lancet, 1974, 2, 1384.

10 Smith GS, Walford RL, Shepard CC, Payne R, Prochazka GJ. Histocompatibility antigens in leprosy. Vox Sang, 1975, 28, 42.

11 Takata H, Sada M, Ozawa S, Sekiguchi S. HLA and mycobacterial infection: increased frequency of B8 in Japanese leprosy. Tissue Antigens, 1978, 11, 61.

12 Thorsby E, Godal T, Myrvang B. HL-A antigens and susceptibility to diseases. II. Leprosy. Tissue Antigens, 1973, 3, 373.

13 Youngchaiyud U, Chandanayingyong D, Vibhatavanija T. The incidence of HLA antigens in leprosy. Vox Sang, 1977, 32, 342.

14 Chakravartti MR, Vogel F. A Twin Study on Leprosy. Stuttgart: Georg Thieme, 1973.

15 Newell KW. A n epidemiologist's view of leprosy. Bull WHO, 1966, 34, 827.

16 Spickett SG. Genetics and the epidemiology of leprosy. I. The incidence of leprosy. Lepr Rev, 1962a, 33, 76.

17 Spickett SG. Genetics and the epidemiology of leprosy. II. The form of leprosy. Lepr Rev, 1962b, 33, 173.

${ }^{18}$ Fine PEM, Wolf E, Prichard J, Watson B, Bradley DJ, Festenstein H, Chacko CJG. HLAlinked genes and leprosy: a family study in Karigiri, South India. J Infect Dis, 1979, $140,152$.

19 Rachelefsky G, Terasaki PI, Park MS, Katz R, Siegel S, Saito S. Strong association between B-lymphocyte group-2 specificity and asthma. Lancet, 1976, 2, 1042.

20 Reinertsen JL, Klippel JH, Johnson AH, Steinberg AD, Decker JL, Mann DL. B-Lymphocyte alloantigens associated with systemic lupus erythematosis. $N$ Engl J Med, 1978, 299, 515.

21 Stoner GL, Touw J, Belehu A, Naafs B. In-vitro lymphoproliferative response to Mycobacterium leprae of HLA-D-identical siblings of lepromatous leprosy patients. Lancet, $1978,2,543$.

22 de Vries RRP, Mehra NK, Vaidya MC, Gupte MD, Meera Kahn P, van Rood JJ. HLAlinked control of susceptibility to tuberculoid leprosy. In: de Vries RRP, The HLA System and Infectious Diseases. S-Gravenhage: Pasmans, 1979.

23 Ridley DS. Histological classification and the immunological spectrum of leprosy. Bull WHO, 1974, 51, 451 . 
24 Ridley DS, Jopling WH. A classification of leprosy for research purposes. Lepr Rev, $1962,33,119$.

25 Ridley DS, Waters MFR. Significance of variations within the lepromatous. group. Lepr Rev, 1969, 40, 143.

${ }^{26}$ Mittal KK, Mickey RR, Sigal BP, Terasaki PI. Serotyping for homotransplantation. XVIII. Refinement of microdroplet lymphocyte cytotoxicity test. Transplantation, 1968, 6, 913.

27 Villarreal JO. Control of leprosy in Morelos. Int J Lepr, 1979, 47, 331.

28 Skamene E, Kongshavn PAL, Sachs DH. Resistance to Listeria monocytogenes in mice: genetic control by genes that are not linked to the H-2 complex. J Infect Dis, 1979, 139, 228. 